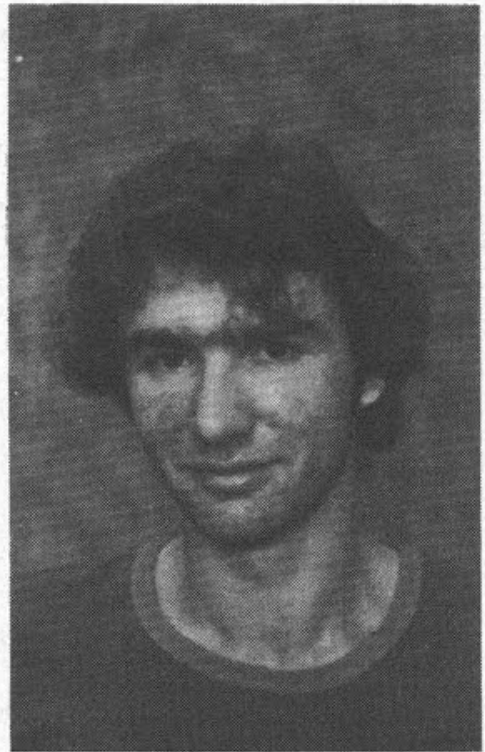

Paul Libich

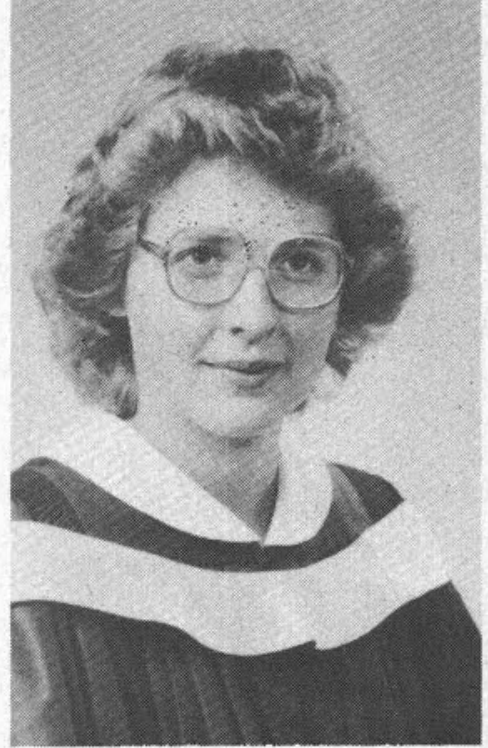

Lois Helen Pelchat

\section{Rocky Mountain}

Paul Libich, of St. Paul, Alberta, was awarded the Resource Management prize offered by the Rocky Mountain Section. The prize consists of a Resource Management text of his choice and a cash award of twenty-five dollars.

Students in the final year of the two-year Forest Technology program attend the Forest Technology School at Hinton, Alberta, where principles of renewable resource planning are used by the students in applied forestry work. The major assignment running the entire year is a Resource Management Plan for a specified forest area of 2900/ha. The result is a comprehensive management plan which allows the student to apply the principles of multiuse management on an area of varied conditions and uses.

The Rocky Mountain Section awards this prize to the student preparing the best report in recognition of the work it entails.

Paul worked with the Alberta Forest Service before entering the forestry course and is now employed by Canyon Creek Forest Products, Ltd., of Valemount, British Columbia.

Lois Pelchat is the recipient of the Canadian Institute of Forestry medal at the University of Alberta in 1979. She came from Kimberly, B.C. to enter the University in 1975. Lois won a Zeidler scholarship in 1976/77 and the Percy Clubine Memorial Bursary in 1977/78 and graduated with distinction and first class standing in the spring of 1979. St. Regis (Alberta) Ltd. nominated her as an outstanding tree planter in 1977

In 1978 Mrs. Pelchat went to Sweden on a forestry exchange program with the Royal College of Forestry. Today she works as a supervisor for St. Regis (Alberta) Ltd. She is an excellent cook, a charming person, and a very able forester and supervisor. Lois married Michael Pelchat who is also a forester and who also works for St. Regis (Alberta) Ltd. at Hinton, Alberta.

\section{Vancouver}

The April dinner meeting, the last in the Section's " 50 th Anniversary" year of celebration, was devoted to a review of foresters as seen through the eyes of environmentalists. Phil Gilbert served as moderator for the three-man panel.

Cliff Stainsby, Executive Director of the Society for Pollution and Environmental Control, led off the discussion by outlining SPEC's multi-use, ecological perspective of forests and forestry. From his viewpoint, the state of forest management in B.C. is dismal. The forest is being over-committed and over-cut because inaccessible stands and non-commercial species are not taken into account in AAC calculations. He noted certain apparent discrepancies between the objectives of the ABCPF, and actual accomplishments in terms of informing and protecting the public. He urged foresters to speak out on behalf of the public interest in forest management regardless of employer interests.

Bill Otway, Executive Director ot the B.C. Wildlife Federation, defined a conservationist as one who believes in and works for the "wise use" of natural resources. The forester's role is to ensure the future existence of the forest resource. He quoted exte-1 sively from Forest Service circular 2828 , and stated that we should not hesitate to restrict logging that is likely to be destructive of land productivity. In recent Queen Charlotte Islands controversy he felt that both fisheries and forestry managers had "sold out" their resource responsibilities.

The final panellist was Ken Farquharson, Vice-Chairman of the Outdoor Recreation Council of B.C., who described his personal "voyage of discovery" in B.C. forestry matters. $\mathrm{He}$ has heard much talk of integrated resource management, but hasn't seen any results on the ground. Citing the 1973 study of the Kinbasket-Canoe area, he recalled poor inventories, lack of policy, ineffective BCFS organization, and the absence of a coherent approach to land management. Farquharson recognized that some changes have occurred, 
but mainly in intent. The new B.C. Forest Act he dismissed as a "housekeeping, tidying-up act", containing no important new directions, incentives or ideas for handling the problems identified. Problems that foresters should now address include:

1) transition from an old-growth to a second-growth economy with minimum social/economic upheaval; 2) emphasis on "economic yield" as opposed to simple industrial growth; 3) need for "environmental repair" investments; 4) strengthened education of foresters, up-grading programs for both technicians and professionals, and public education about forestry; 5) earning back foresters' lost reputation for integrity.

A very lively discussion ensued. Mike Painter thanked the speakers for their presentations, suggesting that it is useful (once in a while) to learn what others think of foresters, and how they view our actions.

P. G. Gilbert

\section{SAF Puget Sound Section Hosts Vancouver Section at Pack Forest}

Twenty-five people from the Vancouver Section (including members, their wives and children) visited the Charles Lathrop Pack Forest near Puyallup, Washington, on June 9, 1979. Our hosts were members of the Puget Sound Section, Society of American Foresters, and the Pack Forest staff of the College of Forestry, University of Washington. They kindly arranged for clear, sunny weather, spectacular views of Mount Rainier, and that highlight of all trips to the woods: a fine lunch.

The Pack Forest, managed by the University of Washington as an experimental field station and student training area, originated in 1926 as a gift of 160 acres from Mr. Charles Lathrop Pack, lumberman and conservationist. The Forest now comprises over 2,000 acres, of which 650 acres carry mature, 190-year-old Douglas fir, hemlock and cedar. The balance consists mostly of 55-year-old second growth $\mathrm{fir}$, of fire origin. Stumpage revenue from the 1-2 million $\mathrm{fbm}$ cut per year (about 50 acres) provides over $90 \%$ of the Pack Forest operating budget.

Nursery operations at the Pack Forest provide seedlings for reforestation on the area, as well as for research projects. Greenhouse temperature and humidity, soil $\mathrm{pH}$ and conductance, and nutrient content of foliage are monitored, for current seedling quality control and future improvement of cultural techniques. Nearly 75,000 container seedlings of various conifer and broadleaf species are produced annually, as well as 60,000 Douglas fir western hemlock and Ponderosa pine transplant seedlings.

Considerable research effort is currently aimed at the use of sewage sludge as a source of nutrients to improve forest productivity. Objectives of the study include: assessment of the response of forest ecosystems; analysis of engineering and economic problems of sludge handling and application; evaluation of overall environmental soundness. Eighty acres of clearcut land and 35 acres of existing forest have so far been treated, with applications ranging from 540 tons to 1,350 tons of sludge per acre. Early results show exceptional growth gains (both basal stem diameter and height) for Douglas fir, less response in sitka spruce and western hemlock, and a net loss in western red cedar; following treatment. Trials are also under way with wastewater; in 1978 the aboveground biomass production in a 4 -year-old Douglas fir plantation was about three times greater when irrigated with wastewater as compared with riverwater.

Special thanks are due to Dave Thomas, Dale Cole and Steve Archie of the SAF, and Mike Painter of the CIF, for organizing this outing. The good fellowship and interesting technical discussions we experienced should encourage continuance of this informal exchange with our American neighbours in future years.

Philip Cottell

\title{
SENIOR SILVICULTURIST
}

\author{
Whonnock Forest Products Limited is a Canadian \\ owned forestry company headquartered in Vancouver.
}

The Company currently has Timber Sale Harvesting Licences in eight coastal Public Sustained Yield Units.

A major Company intensive forestry program is planned to commence shortly.

The candidate will require a solid academic and practical background in all phases of intensive forestry practices. Reporting to the Chief Forester, the candidate will be expected to develop and manage all intensive forestry programs.

Salaries and benefits will be most attractive to the successful candidate.

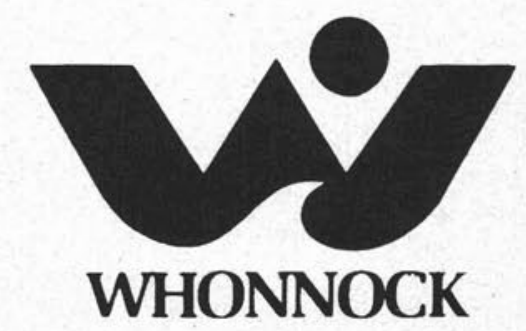

Kindly send resume or contact:

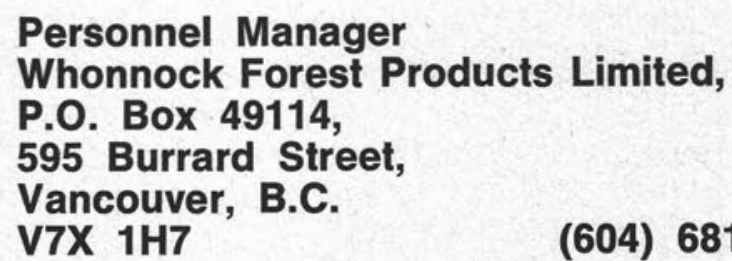

